MARCIN POLAKOWSKI

Instytut Politologii UMK

\title{
Pielgrzymi w obcym świecie. Michaela Oakeshotta nawiązania augustyńskie
}

Dróba porównania dzieła Michaela Oakeshotta z filozofią św. Augustyna z Hippony może być odczytywana jako niezwykle zaskakująca. Inspiracji i źródeł myśli Oakeshotta zazwyczaj jego badacze dopatrują się u zupełnie innych myślicieli, w nurtach refleksji raczej odległych od filozofii augustyńskiej. Jeśli chodzi o wczesne dzieła Oakeshotta, często identyfikuje się wpływ brytyjskich idealistów takich jak Francis H. Bradley, Robin G. Collingwood czy Bernard Bosanquet ${ }^{1}$. Powiada się o sporym szacunku Oakeshotta dla filozofii niemieckiej ${ }^{2}$, w tym naturalnie dla heglizmu³. Za filary jego filozofii,

Temat związków filozofii Oakeshotta z brytyjskim idealizmem omawia D. Boucher, The Creation of the Past: British Idealism and Michael Oakeshott's Philosophy of History, „History and Theory", vol. 23, no. 2, 1984, s. 193-214. Zob. też J. L. Auspitz, Individuality, Civility, And Theory: The Philosophical Imagination of Michael Oakeshott, „Political Theory”, vol. 4, no. 3, 1976, s. 262-267.

Oakeshott w połowie lat 20. dwukrotnie przebywał w Niemczech (w Marburgu i Tybindze), studiując teologię, niemiecką filozofię i literaturę. R. Grant, On Writing Michael Oakeshott's Biography, wystapienie konferencyjne, Colorado College, 25.09.2003, dostępne: http://www.michael-oakeshott-association.org/pdfs/conf03_grant.pdf [7.03.2008]. T. Fuller, An Introduction: Michael Oakeshott's Achievement, „The Political Science Reviewer”, vol. XXI, 1992, s. 1.

N. Wood, A Guide to the Classics: The Skepticism of Professor Oakeshott, „The Journal of Politics”, vol. 21, no. 4, 1959, s. 647-652. H. Wells, The Philosophical Michael Oakeshott, "Journal of the History of Ideas", vol. 55, no. 1, 1994, s. 133. 
zdradzające jej nowożytne zakorzenienie, uznaje się Benedykta Spinozę, a zwłaszcza Tomasza Hobbesa4.

Badanie filozofii Augustyna, w kontekście zainteresowania spuścizną intelektualną Oakeshotta, może wydawać się tym bardziej wątpliwe, jeżeli poprzestaniemy na powszechnym oglądzie Hippończyka jako nade wszystko teologa, myśliciela teocentrycznego, organizatora życia kościelnego, biskupa czy Doktora Kościoła. Religia wszakże nie leżała w centrum zainteresowań Oakeshotta, w różnych kontekstach i formach stając się przedmiotem refleksji zaledwie kilka razy ${ }^{5}$. Nie ma też w jego pismach śladów większego zainteresowania filozofią chrześcijańską czy teologią. Jeśli Oakeshott poświęcał religii nieliczne teksty lub stosowne fragmenty w innych pismach, czynił to zawsze w ujęciach nieortodoksyjnych i niedogmatycznych, wpasowanych w jego ogólną ontologię i epistemologię, stawiającą w centrum specyficznie, idealistycznie i indywidualistycznie pojęty ludzki podmiot, filtrujący informacje z zewnątrz, strukturyzujący i nazywający świat doznań, doświadczeń i wrażeń, mogący w dużej mierze zgłębić, a i to w stopniu wysoce niedoskonałym, jedynie świat materialny ${ }^{6}$.

Nieuzasadnionym uproszczeniem wydaje się jednak stawianie nieprzekraczalnego muru pomiędzy dziełem filozofa z Tagasty a pismami Oakeshotta. Augustyn wszak w ogromnej części swego bogatego dzieła, prócz dociekań o charakterze teologicznym, prowadził rozmyślania o charakterze antropologicznym i historiozoficznym, przedstawiające sytuację człowieka w świecie. Również u Oakeshotta rozważania o charakterze filozoficzno-politycznym opierają się na określonej antropologii oraz teorii etycznej, będących zresztą - wedle niego samego oraz komentatorów - prymarną wobec dociekań politycznych częścią całego dzieła. Oakeshottowskie kategorie w tych obszarach wydają się, pośrednio lub bezpośrednio, odwoływać do prac Augustyna.

${ }^{4}$ O Oakeshottcie jako obrońcy nowoczesności traktuje książka E. Podoksik, In Defence of Modernity: Vision and philosophy in Michael Oakeshott, Exeter 2003, s. 268. Za jednego z przedstawicieli „innej nowoczesności” uznała brytyjskiego myśliciela również: A. Bielik-Robson, Inna nowoczesność: Pytania o wspótczesna formutę duchowości, Kraków 2000, s. $146-152$.

5 Glenn Worthington wymienia tutaj, jeśli chodzi o fragmenty poświęcone wprost religii, jedynie cztery strony w Experience and Its Modes, sześć kolejnych w On Human Conduct, dwa wczesne eseje (w tym Religion and the Moral Life) oraz kilka recenzji. G. Worthington, Michael Oakeshott and the City of God, „Political Theory”, vol. 28, no. 3, 2000, s. 378.

6 M. Oakeshott, Experience and its Modes, Cambridge 1933, s. 31. 


\section{Civitas Dei i civitas terrena Augustyna}

Szczególnie ważne dla rozpatrywania kwestii ewentualnej korespondencji między niektórymi elementami filozofii Augustyna i Oakeshotta, wydaje się przedstawienie dzieła tego pierwszego w kluczowym punkcie rozróżnienia dwóch pojęć historiozoficznych, odnoszących się zarówno do problemu życia zbiorowego, jak i sytuacji pojedynczego indywiduum w społeczności ziemskiej. Chodzi oczywiście o opis dwóch zbiorowości, wspólnot, civitates $^{7}$ - Bożej (civitas Dei) i ziemskiej (civitas terrena). Ów augustyński obraz, zdaje się bowiem - według Oakeshotta - po raz pierwszy, a może jedyny w historii myśli chrześcijańskiej, tak przekonująco opisywać egzystencjalną sytuację człowieka w świecie.

Dla najważniejszego chrześcijańskiego filozofa starożytności, inspirowana Biblią, opozycja dwóch civitates miała raczej charakter moralny, aniżeli historyczno-polityczny. Była rozróżnieniem religijno-mistycznym, nie zaś instytucjonalnym. Przekraczała ramy wszelkich ziemskich pojęć, takich jak państwo czy Kościół ${ }^{8}$, symbolizując raczej to, co dobre i złe w świecie, świat prawdziwych wartości i świat ułudy, ufundowany na ludzkiej pysze. Od pierwiastków obu civitates nie miało być wolne żadne dzieło, w którym uczestniczy człowiek. Sam Kościół, choć włączony przez Augustyna w ramy civitas Dei, nie miał być nim całkowicie.

Główną cechą obywateli obu civitates jest określony węzeł pewnej zgodności ${ }^{9}$, rozumiany jednak raczej jako dyspozycja, skłonność do danych zachowań, wynikająca z określonego celu i obiektu miłości obywateli, a nie ściśle określony, kompleksowy, jednoczący model postępowania czy szczegółowy kodeks etyczny. Spoistość całości utrzymuje wspólne prawo. Civitas Dei jest poddana prawu wiecznemu (lex aeterna) ustanowionemu przez Boga, jest połączona wspólnym oczekiwaniem na radość zbawienia ${ }^{10}$. Oczekiwanie to odbywa się jednak w świecie doczesnym, gdzie jej członkowie poddani są prawu naturalnemu (lex naturalis) oraz prawu pozytywnemu, doczesnemu (lex temporalis), które akceptują, kierując się regułami cnoty obywatelskiej i moralnej. Civitas Dei w swym doczesnym wymiarze narażone jest na oddzia-

$7 \quad$ W języku polskim łacińskie wyrażenie civitas z filozofii augustyńskiej, tłumaczone było różnorako: społeczeństwo, społeczność, państwo, miasto. Sam Augustyn używał zresztą terminu łacińskiego zamiennie z innymi (societas, populus itp.). W niniejszym tekście posługiwał będę się oryginalnym pojęciem civitas, gdyż tylko on zdaje się zapobiegać niepotrzebnemu zawężeniu jego sensu. Por. S. Jóźwiak, Państwo i Kościół w pismach św. Augustyna, Lublin 2004, s. 21.

8 S. Kowalczyk, Człowiek i Bóg w nauce świętego Augustyna, Warszawa 1987, s. 158.

9 T. Szczech, Państwo i prawo w doktrynie św. Augustyna, Marcina Lutra i Jana Kalwina, Łódź 2006 , s. 100 .

10 S. Jóźwiak, dz. cyt., s. 32. 
ływanie i zmieszanie z civitas terrena, wspólnotą zniewolonych, ogarniętych pychą osobników, o zredukowanej, ograniczonej, ziemskiej perspektywie. Obie kategorie civitas, choć diametralnie się od siebie różniące, to porządki przenikające się wzajemnie i ścierające się w walce o duszę każdego człowieka. Obywatele civitas Dei poddają się łasce Bożej, podczas gdy obywatele civitas terrena ostatecznie bez walki pogrążają w zepsutej grzechem naturze ${ }^{11}$. Poddają się ziemskim nakazom tylko ze strachu przed karą. Grzech, który jest ich węzłem zgodności, to grzech pożądliwości ${ }^{12}$.

Obywatele augustyńskiego civitas Dei to miasto wierzących i pokornych $^{13}$, wspólnota świętych, odwróconych od ludzkich dóbr, używających rzeczy ziemskich jedynie jako środków do celu wyższego. Wyróżnia ich życie według ducha ${ }^{14}$ oraz skromność, będąca zaprzeczeniem pychy, wynikającej z pożądliwości i pragnienia mocy. Świat i wszystko, co z nim związane, nie jest dla jego obywateli celem istnienia. Traktują oni raczej świat doczesny jako etap w drodze do szczęśliwości w Bogu. Dóbr ziemskich jedynie używają, posługują się (uti), a nie "cieszą" i napawają się nimi (frui $)^{15}$. Żyją więc wedle woli Bożej, a nie zgodnie z ludzkimi standardami. Podobnie jak civitas terrena, łączy ich miłość, tyle, że nie jest to miłość do siebie samego, miłość własna, lecz miłość do Stwórcy.

Obywatele civitas terrena ufność całą pokładają w życiu ziemskim, materialnym, doczesnym ${ }^{16}$. To, co ludzkie utożsamiają z całością egzystencji, odrzucając świadomie wszystko, co święte. W tym widzą sens, kres oraz absolutny cel istnienia. Dobra ziemskie jawią im się jako cel sam w sobie, do którego dążą pobudzani egoizmem oraz pragnieniem zaspokojenia ambicji i uzyskania satysfakcji, zakorzenionych w immanencji. Ponadto, owe dobra nic więcej nie znaczą, nie są symbolem miłości Boga tak, jak dla obywateli civitas Dei, a zatem właściwą postawą wydaje się im być ich prędkie gromadzenie (nabywanie, zdobywanie, podbijanie), gdyż inne postępowanie nie prowadzi do niczego wzniosłego.

11 Biblijnymi prefiguracjami tej antynomii są dwa miasta: Jerozolima i Babilon, czy też historia Kaina i Abla: „Kain należał do społeczności ziemskiej (ad hominum civitatem), założył też miasto, jakby dla zaznaczenia, że jego królestwo jest z tego świata. Abel, który zapoczątkował państwo Boże (ad civitatem Dei pertinens) nie założył miasta, jakby dla potwierdzenia, że życie ziemskie jest tylko pielgrzymką do Nieba". T. Wnętrzak, Znaczenie pojęć filozoficzno-politycznych w De Civitate Dei św. Augustyna, Kraków 2002, s. 100.

12 T. Szczech, dz. cyt., s. 101.

13 Św. Augustyn, Państwo Boże, przeł. W. Kubicki, Kęty 1998, s. 529.

Tamże, s. 508.

5 T. Wnętrzak, dz. cyt., s. 93. S. Jóźwiak, dz. cyt., s. 25.

16 Św. Augustyn, dz. cyt., s. 686. 


\section{Człowiek ,doczesny” i człowiek „religijny” Michaela Oakeshotta}

Opis ludzkiego życia szkicowany jest przez Oakeshotta w kontekście jego sprzeciwu wobec wszelkich nieuzasadnionych roszczeń człowieka, opisywanych jako gnostyckie lub pelagiańskie. Roszczenia te polegać mają na nieuzasadnionej wierze, że wybawienie człowieka leży w sferze ludzkich możliwości. W tej perspektywie kluczowym jest podjęcie decyzji co do modelu postępowania, jaki należy w życiu przyjąć. Wybór ten jest u Oakeshotta opisywany po augustyńsku.

Kluczowym czynnikiem dla problemu ogarniania ludzkiego doświadczenia jest, według angielskiego filozofa, kwestia oczekiwań, jakie człowiek żywi wobec świata. Może więc poszukiwać usilnie w świecie wypełnienia swych doraźnych pragnień albo zachwycić się w świecie tym, co godne zachwytu, traktując go jednak nieodmiennie jako coś czasowego, ograniczonego i przelotnego. Nie staje się wówczas człowiek zdominowanym przez doczesność i doraźne roszczenia, jakie można wobec niej żywić. Dążenie do wypełnienia konkretnych celów zawsze stanowi pewną część ludzkiego życia, jednak nie może być rozumiane jako całość ludzkiego doświadczenia, stanowić sens całości i być wektorem wyznaczającym kierunek ludzkiego postępowania. Rudymentarną częścią właściwego „bycia w świecie” jest bowiem dla Oakeshotta poszukiwanie tego, co wykracza poza przetrwanie i ziemskie cele, nawet jeśli ostatecznie rozum podpowiada nam, że żyjemy w chaotycznym i pozbawionym sensu kosmosie ${ }^{17}$.

W eseju Religion and the World angielski teoretyk rozwija zasygnalizowaną dystynkcję na tyle, iż może być ona porównywana $\mathrm{z}$ augustyńską koncepcją dwóch mistycznych civitates. Proponuje bowiem rozróżnienie dwóch modelów osobowości moralnej. Chodzi mianowicie o moralność ziemską, doczesną (worldly) oraz religijną (religious). Oba pomysły na to, jak żyć, są odmienne i niewspółmierne wobec siebie, lecz w zasadzie nigdy nie występują w postaci czystej.

Człowiek „doczesny” jest skoncentrowany na gromadzeniu i korzystaniu z dóbr nietrwałych, jednym z jego głównych celów jest osiąganie zaszczytów. Wartość jego ego jest bowiem mierzona jedynie przez zewnętrzne osiągnięcia, a zatem waga poszczególnych podejmowanych działań jest de facto wyznaczana przez innych, zależy od zewnętrznych, doczesnych standardów ${ }^{18}$. Trwałości i stabilności człowiek „doczesny” poszukuje w świe-

G. Worthington, Michael Oakeshott..., s. 377.

Tamże, s. 379. 
cie zewnętrznym, poza sobą, w poszerzaniu wiedzy, w sukcesach w dziedzinie sztuki czy nauki ${ }^{19}$. Wewnętrzne spełnienie jest dla niego pojęciem niezrozumiałym, a refleksja nad nim przekładana w przyszłośćc ${ }^{20}$. W życiu wypełnionym gonitwą za ziemskimi dobrami ludzie oceniani są przez pryzmat ich przydatności w osiąganiu tychże dóbr, podobnie jak rzeczy ujmowane są pod kątem ich użyteczności. Nie ma tu zasadniczo znaczenia zakres poszczególnych celów doczesnych, ponieważ najistotniejszy jest ich charakter, niechybnie rzutujący na całościowe postrzeganie świata. Mogą być one osiągane zasadniczo jedynie poprzez typ aktywności, który Oakeshott nazywa „pracą” (work), czyli ustawiczne i pracochłonne działanie, nieuniknione dla stworzeń prowadzonych przez pragnienia, w którym świat naturalny jest postrzegany jako źródło zaspokajania tych pragnieńen ${ }^{21}$.

Przeciwieństwem takiej postawy jest, przedstawiona przez Oakeshotta, figura człowieka „religijnego”. Dla niego spełnienie nie jest czymś odległym, nieokreślonym, abstrakcyjnym. Spełnienie dokonuje się w każdym momencie życia, choć jest ono postrzegane specyficznie, nie jako całkowite wybawienie od trosk, zmartwień, zła, bólu, lecz raczej jako czerpanie przyjemności z życia takim, jakie ono jest, z ludzkich aktywności, którym sami lub w interakcji z innymi możemy nadawać sens. Nie ma to być w żadnym razie przyjemność wynikającą z przedmiotowego podejścia do wszystkiego wokół, przeciwnie - wystrzega się ona wszelkiej definitywności, z zasady ma być postawą niedookreśloną, otwartą, gotową do ciągłego doświadczania. Tak pojęte spełnienie w życiu doczesnym, któremu Oakeshott nadaje charakter wyraźnie indywidualistyczny, jest co prawda celem ostatecznym, jednak zawsze dokonuje się przez cele pośrednie, przez działania, których wartość wynika z nich samych ${ }^{22}$. To właśnie one, praktyki bezinteresowne, takie jak np. miłość, przyjaźń, poezja czy kontemplacja, stanowią rdzeń aktywności człowieka „religijnego”. Są rytuałami wypełnianymi nie z uwagi na namacalny rezultat czy konkretną korzyść. Praktyki doczesne stanowią zaś jedynie przykry obowiązek, są podejmowane o tyle, o ile są konieczne do fizycznego i psychicznego przetrwania ${ }^{23}$. Prawdziwym probie-

19 M. Oakeshott, Religion and the World, w: Tenże, Religion, Politics and the Moral Life, New Haven 1993, s. 32-33.

20 E. Corey, Being otherworldly in the World: Michael Oakeshott on Religion, Aesthetics and Politics, praca doktorska, Louisiana State University, 2004, s. 36, dostępne: http://etd.lsu.edu/ docs/available/etd-11102004-212928/unrestricted/Corey_dis.pdf [10.03.2008]. Cytowana dysertacja została wydana jako książka w roku 2006 przez University of Missouri Press.

21 M. Oakeshott, Work And Play, „First Things”, czerwiec-lipiec 1995, dostępne: http://www.firstthings.com/article.php3?id_article=4057 [10.03.2008].

22 E. Corey, dz. cyt., s. 36.

23 Tamże. 
rzem wartości danych rzeczy jest zazwyczaj ich trwałość, czyli fakt, że są długotrwale praktykowane, mimo że niczemu nie służą. Tenże „religijny” system wartości opiera się więc na swoistej autoafirmacji jaźni. Doczesne powodzenie nie jest oznaką wartości jej przymiotów ${ }^{24}$. Pozwala to chronić jedność doświadczenia moralnego, oswajać zmienność i czasowość świata. Pozwala podejmować grę (play) ze światem, w której zarzucamy jednokierunkowe poszukiwanie ziemskich dóbr i substancjalnej satysfakcji, wyzbywając się jednocześnie związanych z nimi obaw ${ }^{25}$.

\section{Podobieństwa i różnice}

Zarówno Oakeshott, jak i Augustyn próbują przedstawić dwa sposoby postępowania, poznawania i ogarniania świata. Obie wizje są zgodne co do wielu intuicji opisujących sytuację człowieka w świecie, obaj myśliciele postrzegają ją pesymistycznie. Koncentrują się na doniosłości konstatacji nieuchronnej śmiertelności człowieka i nietrwałości dzieł ludzkich, która posiadać ma centralne znaczenie dla opisywania wyborów, jakich dokonuje. Skazuje bowiem człowieka na poczucie niespełnienia, niemożliwe do całkowitego wyrugowania, wynikające z przemijalności wszystkiego, co ludzkie, wszelkich przedsięwzięć, działań i dzieł. Owe permanentne niespełnienie nieuchronnie owocuje bólem zawiedzionych oczekiwań, cierpieniem niewypełnionych celów, smutkiem niechcianych nieszczęść, ciężarów, defektów ${ }^{26}$. Wszystkie starania ludzkie dążące do przekroczenia tych egzystencjalnych warunków istnienia są skazane na porażkę, a zatem lepszym wyjściem jest brak przywiązania się do nich. Bycie w świecie i tak wymaga wielu ustępstw na rzecz doczesności, więc ich dodatkowe piętrzenie zarówno dla Augustyna, jak i dla Oakeshotta jest zwyczajnie nierozsądne. Podróż przez doczesność uczy nas wiele, pozwala nabywać nowe doświadczenia, modyfikować ideały, wskazywać to, co w danej sytuacji lepsze, rozwijać nasze samorozumienie i wrażliwość w życiu zbiorowym, jednak ostatecznie i tak jest bitwą, której wynik jest $\mathrm{z}$ góry znany ${ }^{27}$. U żadnego $\mathrm{z}$ omawianych filozofów diagnoza ta nie ma charakteru obsesyjnego, paraliżującego strachu przed życiem, wręcz przeciwnie - pozwala z pogodną rezygnacją ułożyć się z rzeczywistością i wyzbyć się utopijnych marzeń, złagodzić frustracje i zawody, wynikające z naiwnych nadziei przezwyciężenia nieprzezwyciężalnego. Pozwala częściowo pokonać niepohamowany strumień pragnień, hobbesowskie nieustanne pragnienie mocy, czyli właściwą człowiekowi pogoń za kolejnymi

G. Worthington, dz. cyt., s. 380 .

M. Oakeshott, Work....

M. Oakeshott, On Human Conduct, Oxford 1975, s. 81.

M. Oakeshott, Religion..., s. 44. 
celami, zapewniającymi jedynie krótkotrwałą i pozorną satysfakcję ${ }^{28}$. Jej konsekwencją może też być zwrócenie uwagi na to, co najbardziej wartościowe, co nadaje sens egzystowaniu na ziemi.

Obaj myśliciele w swych rozważaniach odwołują się do pojęcia religii, choć diametralnie różnie je rozumieją. U Augustyna stanowi ona część obiektywnego porządku rzeczy, rozpoznaną rzeczywistość nadprzyrodzoną. Podział na civitas Dei i civitas terrena przebiega w poprzek nie tylko świata doczesnego, ale i nadprzyrodzonego, w gruncie rzeczy to właśnie z niego, $\mathrm{z}$ buntu aniołów przeciwko Bogu, bierze on swój początek ${ }^{29}$. Wartość światu nadaje zaś jedynie chwała jego Stwórcy i jego określony plan zbawczy. U Oakeshotta rzecz musi wyglądać inaczej. On bowiem utrzymuje, że całość ludzkiego doświadczenia jest przekazywana, filtrowana i zapośredniczana przez ludzki podmiot. To, co nadprzyrodzone jest $\mathrm{w}$ istocie niepoznawalne siłami ludzkiego rozumu, a zatem wykluczone jest zarysowanie wyraźnych konturów naturalnego i nadprzyrodzonego. Porządek nadprzyrodzony, nawet jeśli w niego wierzymy, pozostawia nas samych sobie w społecznym kosmosie $^{30}$. Pojęcia „religia” Oakeshott używa więc w swych pismach w sposób dalece heterodoksyjny i niedogmatyczny. Sam zresztą opisując dwa główne nurty rozumienia dualizmu naturalnego-nadnaturalnego $\mathrm{w}$ rozwoju chrześcijaństwa, odrzuca oba $\mathrm{z}$ nich $^{31}$. To, co przedstawia, to próba skomentowania właściwego sposobu postępowania w świecie doczesnym. Przymiotnik „religijny”, w tym kontekście, oznacza więc dla Oakeshotta próbę usensownienia całego świata praktyki, z której żadne działanie nie jest $z$ definicji wyłączone, a jej scenariuszów może być więcej aniżeli te zapisane w niebiosach.

W całym tym procesie zarówno Augustyn, jak i Oakeshott podkreślają wagę ludzkiego wyboru. Augustyn był pierwszym filozofem, który tak mocno

${ }_{28}$ Zbieżność niektórych założeń, diagnoz i konkluzji między Augustynem i Hobbesem jest tematem często podejmowanym. Por. M. Cichocki, Wieczny pokój u św. Augustyna. Teologia polityczna wobec filozofii politycznej, „Teologia Polityczna”, nr 1, 2003-2004, s. 185-193.

29 Św. Augustyn, dz. cyt., s. 439-440.

30 Oakeshott w wielu swych pismach i rozmowach dawał do zrozumienia, że jeśli chodzi o religię bliska jest mu postawa fideistyczna, w tym względzie zawsze fascynował się Kierkegaardem czy Pascalem.

31 Wiara wczesnych chrześcijan bazowała na przekonaniu o bliskim, ponownym przyjściu Chrystusa na ziemię, które choć miało posiadać charakter w dużej mierze immanentny, w konsekwencji owocowało rezerwą lub nawet pogardą wobec doczesności, wynikającą z bliskości wydarzeń ostatecznych, oznaczających jej zagładę. Późniejsze zrozumienie posłannictwa Jezusa, roztaczało perspektywę zbawienia, dokonującego się w porządku nadprzyrodzonym, co z kolei samo w sobie deprecjonowało znaczenie świata „ziemskiego”, nawet jeśli wysiłki w nim podejmowane miałyby skutkować nagrodą w innym świecie. M. Oakeshott, Religion..., s. 28-30. 
zaakcentował wartość ludzkiej woli, która, choć zwodzona, jest w istocie „ostatecznym czynnikiem określającym postępowanie człowieka" ${ }^{32}$. Przynależność do danej civitas jest ostatecznie wynikiem ludzkiej decyzji ${ }^{33}$, nawet jeśli wspomaganej nieodzowną łaską Bożą. Oakeshott, podobnie, zawsze podkreślał odrębność, doniosłość i swój dług wobec nowożytnej tradycji filozoficzno-politycznej, zapoczątkowanej przez Hobbesa, a opierającej się na woli ${ }^{34}$. Również i tym razem uwypukla znaczenie „inteligencji w działaniu” (wyrażenie, które preferuje w stosunku do „wolnej woli”), czyli rozumnego rozważania warunków, w których podejmowane jest działanie i odpowiadania na kształt tejże sytuacji, bez której każdy akt wynikałby z naturalnych pragnień czy bezwolnych, zwierzęcych instynktów ${ }^{35}$.

Brytyjski myśliciel definiuje rozróżnienie dwóch rodzajów ludzkiego działania (work-play) w uderzająco podobny sposób do augustyńskiej diady uti-frui, z chęcią używa augustyńskiego wyrażenia civitas peregrina ${ }^{36}$. W obu przypadkach, „ostatecznie liczy się właśnie to, czy potrafimy się wyrwać z okowów codzienności, czy zdobywamy się na tęsknotę za czymś lepszym"37. Zarówno obywatele augustyńskiego civitas Dei, którym powyższe określenie jest przynależne, jak i ludzie „religijni” Oakeshotta jedynie przemieszkują w świecie, pielgrzymują przezeń, w każdej ze społeczności są jedynie „przechodniami”, „wędrowcami”. Zawsze będąc narażonymi na częściowe wyobcowanie, mogą sobie pozwolić co najwyżej na „czasowe osiedlenie", podczas którego będą współpracować z innymi ludźmi na rzecz jakiegoś dobra i z niego korzystać, lecz także z dystansem znosić ciężary ziemskiego porządku (znosić - i nic więcej) ${ }^{38}$. Mają więc ze sobą wiele wspólnego, nawet jeśli w przypadku Augustyna dążą w sprecyzowanym kierunku, zaś u Oakeshotta po prostu idą w nieznane.

M A R C I N P O L A K O W S K I

32 A. MacIntyre, Czyja sprawiedliwość? Jaka racjonalność?, przeł. A. Chmielewski i in., Warszawa 2007, s. 234

33 T. Wnętrzak, dz. cyt., s. 101.

34 Oakeshott wyróżnił trzy główne historyczne nurty filozofii polityki: 1) Rozumu i Natury (Platon); 2) Woli (Hobbes); 3) Woli Racjonalnej (Hegel). Zdystansowanie się od obydwóch tradycji o mocnych inklinacjach racjonalistycznych (Platon i Hegel), sugerowałoby duży dystans Oakeshotta wobec racjonalizmu jako takiego, a nie tylko jego nowożytnej odmiany. M. Oakeshott, Introduction to Leviathan, w: Tenże, Hobbes on Civil Association, Indianapolis 1975, s. 7-8.

35 E. Corey, dz. cyt., s. 54.

36 Termin peregrinus oznaczał obcego, cudzoziemca, mieszkańca, lecz nie obywatela, jak również podróżnego, pielgrzyma. Por. T. Wnętrzak, dz. cyt., s. 102.

37 Tamże, s. 101

38 Tamże, s. 101-102. 


\section{Pilgrims in The Other World. Michael Oakeshott's augustinian references}

This article is a short study of Michael Oakeshott's philosophy with the emphasis put on his religious convictions. This non-doctrinal view of religion is identified here by noting Oakeshott's philosophical debt to Augustine. The relationship between Oakeshott's and Augustine's thought are considered and startling similarities between these two philosophers are underlined.

Oakeshott's „transposed augustinianism” lies in an idea of living entirely in the world without becoming worldly. Human beings should appreciate the beauty and fathomlessnes of creation without being excessively proud or focused on earthly desires. This non-instrumental attitude to the others is described as living in the world as pilgrims or ,alien sojourner”. It is also an element of a crusade against prideful assumptions that man can overcome, his own limits, imperfections and flaws.

Oakeshott's two worlds are ultimately incomparable because they present two completely different models of the idea how man is supposed to live, which are - like in the augustinian recognition - totally inseparable aspects of moral life in the earth.

Obviously, Oakeshott's view is not only a duplication, but also a reformulation of the idea of being suspended between two completely different orientations in human life. The augustinian idea of the City of God and the city of man is transformed and fitted to Oakeshott's ontology and epistemology. From his perspective, all experience is mediated through the human subject and the idea of the transposed City of God is definitely a part of this experience. 